\title{
Chemical Composition and Detection of Aflatoxin and Genetic Modification in Imported Yellow Corn and Soybean
}

\section{Moshira Aboualfath, Omayama E. Shaltout, Ayman Abo Elyazed,} Said M.Khalil ${ }^{\star}$, Hisham M. Elshishtawy* and Ahmed E. Abdalla

Food Science Department, Faculty of Agriculture, Saba Basha, Alexandria University, Egypt *Plant Genetic Transformation Department and ** Microbial Molecular Biology Department, Agricultural Genetic Engineering Research Institute, Agricultural Research Center, Egypt.

\begin{abstract}
During the last decade, the gap between production and consumption of cereals and legumes in Egypt is compensated by importation from different countries.

The objective of this study was undertaken to investigate the chemical composition and detection of aflatoxins and gentic modification (GM) in imported yellow corn and soybean.

The results of proximate chemical composition showed that imported yellow corn contained protein ranged from 8.75 to $9.80 \%$ and fat ranged from 3.48 to $4.0 \%$ while in Egyptian variety (SC128) protein increased to $10.15 \%$. Imported soybean contained protein ranged from 32.8 to $37.3 \%$ and fat ranged from 16 to $20.8 \%$ while in Egyptian variety (Giza 111) protein increased to $37.8 \%$. Liquid chromatography analysis showed that all imported and local varieties of corn and soybean samples were free of aflatoxins contamination. GM detected that $45 \%$ and $50 \%$ of total imported yellow corn and soybean samples were tested positive for NOS terminator and s335 promotor.

Egypt imports large amount of cereal and legumes from Ukraine, Bulgaria, Brazil, Rumania and USA who considered as the most countries produced GM so the most cereals and legumes in the Egyptian market may be genetically modified.

It is evident from the results that imported yellow corn and soybeans are of high quality because they contained high levels of protein and fat and free from aflatoxin but some are genetically modified (about $50 \%$ of imported samples are GM).

Detection and/or quantification of GM corn and soybeans in processed foods are one of the most important consumer concerns regarding food safety and quality.
\end{abstract}

\section{INTRODUCTION}

Ancient civilizations in the Middle East include cereals and legumes in wellbalanced diets which promoting health benefits for humans (Mahler-Slasky and Kislev, 2010).

The proximate chemical composition of the yellow and white corn showed that the amount of protein ranged from 12.32 to $13.50 \%$, fiber content from 1.05 to $6.47 \%$, fat content from 4.90 to $14.02 \%$, ash content ranged from 0.99 to $1.04 \%$, moisture content ranged from 8.74 .73 to $10.94 \%$ and carbohydrate content ranged from 16.28 to $62.38 \%$ (Oladapo et al., 2017). Qamar et al. (2017) reported that corn contained moisture (11.6-20.0\%), ash (1.10-2.95\%), protein (4.50-9.87\%), fat (2.17-4.43\%), fiber (2.10-26.70\%) and carbohydrates contents (44.60-69.60\%). The same results were found by Feyera (2020).

Soybeans are good sources of protein, lipid, and other nutrients. Soybean possess a very high nutritional value with a relatively high protein (39-45\%) with essential amino acids and oil contents (20-30\%) (Abolude et al., 2012 and Jegadeesan and Kangfu, 2020). Soybean protein products can be good 
substitutes for animal products because, unlike some other beans, soybean offers a "complete" protein profile (Medic et al., 2014 and Çakir et al., 2019).

During storage or export of cereals and legumes, aflatoxins directly or indirectly result in the contamination of crops, which affects the liver, immune system and reproduction after infiltration into human beings and animals (Ubwa et al., 2012). Screening of aflatoxins B1, B2, G1 and G2 levels in maize were detected by different authors (El Hodairy, 2009, Atmaca et al., 2015 and Shamsuddeen et al., 2017). Murshed et al. (2019) investigated the presence of aflatoxins in groundnuts and soybeans that are consumed in Yemen. Some samples were free of aflatoxins, while in only $6.2 \%$ of soybean samples and $22.47 \%$ of groundnut samples, total aflatoxins were beyond the maximum limit of FDA/Yemen standards $(20 \mu \mathrm{g} / \mathrm{kg})$. In addition, in $49.44 \%$ and $27.6 \%$ of the groundnut and soybean samples, total aflatoxins exceed the acceptable level of European Commission $(4 \mu \mathrm{g} / \mathrm{kg})$.

Gene modification techniques have been applied to a number of agricultural crops in order to insert new appropriate traits such as herbicide tolerance, insect and disease resistance, improve the nutritional content of food as protein and fat and feed products and increasing of various desirable traits (Greiner and konietzny, 2008 and Kaur et al., 2010).

The FAOMHO (2000) concluded that risks to human and animal health from the use of genetically modified (GM) crops and enzymes derived from GM microorganisms as animal feed are negligible and FAO/WHO (2001) recognizes the need for continued safety assessments on genetically modified foods before they are marketed to prevent risks to human health and for continued monitoring.

There are several risks for humans from the consumption of genetically modified (GM) food (Paarlberg, 2006), such as GM food have been mentioned to elevate the risks of cancer, increase chances of allergy specially in children, increase the chances of anti-biotic resistance and that is due to the presence of antibiotic resistant genes and also the introduced gene may interact and corporate to the genetic makeup of the consumers (Flachowsky et al., 2013). However, the research to evaluate the extent of these risks is incomplete (Sparrow, 2018 and Shetty et al., 2018).

Among the GM plants corn and soybean are the two main cultivated GM crops in the globe, which covered $32 \%$ and $47 \%$ of the transgenic plants area respectively, and commonly represent as ingredients in many foods (Forte et al., 2005 and James and Brief, 2011). Thus, detection and/or quantification of GM soybeans in processed foods are one of the most important consumer concerns regarding food safety and quality (Mandaci et al., 2014). 
Currently in Egypt, there is a gap between production and consumption of cereal crops, oil crops, sugar crops, legume crops and forage crops (Metz, 1990 and Zohry et al., 2016).

Reducing yield gaps is one of the main goals of food security research in Egypt. However, Egypt remains to be the fourth largest grain importer in the world despite government efforts to increase local production (Rehab Hafez et al., 2019).

The gap between production and consumption of maize in Egypt is estimated by around $45 \%$. This gap is compensated by importation, which put a burden on the country's budget. Egypt's yellow corn production covers less than 20 percent of its feed demand needs. Imports are supplementing the feed manufacturing industry's expanded production. Foreign Agriculture Service (FAS) Cairo forecasts Egypt's corn imports in 2020/21 at 10.0 million metric tones (FAS, 2020).

Egypt's soybean imports in marketing year 2020/21 are forecast at 3.8 million metric tons (MMT).

The aim of this study was undertaken to investigate the chemical composition and detection of both aflatoxins and genetically modified organisms in imported yellow corn and soybean samples.

\section{MATERIALS AND METHODS}

\subsection{Materials}

Eleven imported yellow corn samples and fourteen imported soybean samples were collected during November 2018 up to March 2019.

Six kilograms of each sample were divided into three parts; first part for proximate chemical composition, second for detection of aflatoxins and third part for detection of genetically modified organisms.

All chemicals, solvents and standards were of analytical grade and purchased from Sigma (St. Louis, MO, USA).

\subsection{Methods}

\subsubsection{Proximate chemical composition analyses}

Proximate chemical composition of selected four imported of each yellow corn and soybean samples and one Egyptian variety of each one were determined at Central Laboratory of Residue Analysis of Pesticides and Heavy Metals in Food, Agriculture Research Center, Egypt.

Moisture contents of yellow corn and soybean samples were determined using Mettler Toledo - HR73 Halogen Moisture Analyzer.

Total protein, total fat, fiber and total ash of different samples were determined according to AOAC (2000). 
Nitrogen free extract was calculated by difference, after subtracting the values of moisture, protein, fat, fiber and ash from 100 (Rodrigues et al., 2014).

\subsubsection{Detection of aflatoxins in imported corn and soybean}

Detection of aflatoxins in selected four imported of each yellow corn and soybean samples and one Egyptian variety of each one were determined at Central Laboratory of Residue Analysis of Pesticides and Heavy Metals in Food, Agriculture Research Center, Egypt.

Aflatoxins $\left(B_{1}, B_{2}, G_{1}\right.$ and $\left.G_{2}\right)$ were detected using liquid chromatographic method as described by AOAC Official Method 990.33 (1990).

\subsubsection{Standard aflatoxins}

Transfer appropriate quantity of aflatoxin stock solutions to $50 \mathrm{~mL}$ beaker to contain $500 \mathrm{ng}$ each of aflatoxins $B_{1}$ and $G_{1}$ and $250 \mathrm{ng}$ each of aflatoxins $B_{2}$ and $\mathrm{G}_{2}$. Evaporate mixture to dryness under gentle stream of nitrogen. Add 2-3 $\mathrm{mL} \mathrm{CH}_{2} \mathrm{Cl}_{2}$ and swirl $10 \mathrm{~s}$. Quantitatively transfer to silica gel column with 2 ca I $\mathrm{mL}$ portions of $\mathrm{CH}_{2} \mathrm{Cl}_{2}$, using wash bottle.

\subsubsection{Sample Extraction and filtration}

Transfer $50 \mathrm{~g}$ corn or $50 \mathrm{~g}$ soybean to $1 \mathrm{~L}$ blender jar, add $200 \mathrm{~mL}$ methanol followed by $50 \mathrm{~mL} 0.1 \mathrm{M} \mathrm{HCl}$, and blend $3 \mathrm{~min}$ at high speed. Filter through 24 $\mathrm{cm}$ Whatman No. 1 paper, or equivalent. Collect $50 \mathrm{~mL}$ filtrate.

\subsubsection{Partition}

Transfer $50 \mathrm{~mL}$ filtrate to $250 \mathrm{~mL}$ separatory funnel. Add $50 \mathrm{~mL} 10 \% \mathrm{NaCl}$ solution, swirl, add $50 \mathrm{~mL}$ hexane, and shake gently ca $30 \mathrm{~s}$. Let phases separate and drain lower aqueous layer into another $250 \mathrm{~mL}$ separatory funnel. Discard hexane layer. Add $25 \mathrm{~mL} \mathrm{CH}_{2} \mathrm{Cl}_{2}$ and shake moderately $30 \mathrm{~s}$. If emulsion occurs, break up with clean Pasteur pipet. Let phases separate and drain lower $\mathrm{CH}_{2} \mathrm{Cl}_{2}$ layer through $4 \mathrm{~cm}$ coarse granular, anhydrous $\mathrm{Na}_{2} \mathrm{SO}_{4}$ in glass filter tube. Collect eluate in $250 \mathrm{~mL}$ beaker. Repeat partition with 2 additional $25 \mathrm{~mL}$ portions of $\mathrm{CH}_{2} \mathrm{Cl}_{2}$, and vigorously shake and drain as above. Collect eluate in the $250 \mathrm{~mL}$ beaker. Evaporate eluate on steam bath under gentle stream of nitrogen to 2-3 $\mathrm{mL}$ (1-2 mm layer of eluate covers bottom of beaker).

\subsubsection{Column Chromatography}

Slurry $2.0 \mathrm{~g}$ silica gel with ca $10 \mathrm{~mL}$ ether-hexane $(3+1)$ in $30 \mathrm{~mL}$ beaker, pour slurry into clean up column, and wash beaker with additional $5 \mathrm{~mL}$ etherhexane solvent to effect transfer. Keep stopcock closed and let silica gel settle without tamping. Wash sides of column with $2-3 \mathrm{~mL}$ ether-hexane $(3+1)$, using wash bottle. After gel settles, open stopcock, and, while column drains, add ca $1 \mathrm{~cm}$ anhydrous granular $\mathrm{Na}_{2} \mathrm{SO}_{4}$.Transfer eluate from partition, $\mathrm{F}$, to 
column. Wash lip of beaker with $0.5 \mathrm{~mL} \mathrm{CH}_{2} \mathrm{Cl}_{2}$, using wash bottle, and collect wash in column.

Wash beaker with ca $2 \mathrm{~mL} \mathrm{CH}_{2} \mathrm{Cl}_{2}$ and add wash to column. Do not use more than 5-6 $\mathrm{mL} \mathrm{CH}_{2} \mathrm{Cl}_{2}$ to transfer eluate to column.

With stopcock fully open, add $25 \mathrm{~mL}$ benzene-acetic acid $(9+1)$, and then add $30 \mathrm{~mL}$ ether-hexane $(3+1)$ to column, draining each wash to top of $\mathrm{Na}_{2} \mathrm{SO}_{4}$.Discard washes. Elute aflatoxin with $100 \mathrm{~mL} \mathrm{CH} \mathrm{Cl}_{2}$-acetone $(90+10)$ and collect eluate in $250 \mathrm{~mL}$ beaker. Evaporate eluate on steam bath under gentle stream of nitrogen to ca $6 \mathrm{~mL}$. Quantitatively transfer to $3 \mathrm{dram}$ vial, using 2-3 $\mathrm{mL} \mathrm{CH}_{2} \mathrm{Cl}_{2}$ as wash.

Evaporate eluate almost to dryness on steam bath in an aluminum block under gentle stream of nitrogen. Evaporate remaining $200 \mu \mathrm{L}$ just to dryness under gentle stream of nitrogen by holding vial in palm of hand and slowly rotating vial.

\subsubsection{Derivatization}

Add $200 \mu \mathrm{L}$ hexane to residue from G. Then, add $50 \mu \mathrm{L}$ TFA (using Eppendorf pipet), cap vial, and Vortex mix vigorously for $30 \mathrm{~s}$ (exactly). This procedure must be followed closely to ensure consistent reaction yields. Let mixture stand 5min. Using Eppend or fpipet, add $1.950 \mathrm{~mL} \mathrm{H} \mathrm{H}_{2} \mathrm{O}-\mathrm{CH}_{3} \mathrm{CN}(9+1)$. Vortex mix vigorously for $30 \mathrm{~s}$ (exactly), and let layers separate10min or centrifuge at1000 rpm for $30 \mathrm{~s}$. Concentration is $10 \mathrm{~g} / 2 \mathrm{~mL}$ aqueous $\mathrm{CH}_{3} \mathrm{CN}$.

\subsubsection{LC Determination}

Successively inject $25 \mu \mathrm{L}$ of derivatized standard solutions. Prepare standard curve to check linearity of responses. Inject $25 \mu \mathrm{L}$ TFA-treated test solution (lower aqueous phase). If test peaks are outside linear range, dilute aliquot of TFA-treated test solution to suitable volume with $\mathrm{H}_{2} \mathrm{O}-\mathrm{CH}_{3} \mathrm{CN}(9+1)$, remix on Vortex mixer, and inject another $25 \mu \mathrm{L}$ portion. Calculate individual aflatoxin concentrations as follows. Use responses of standard containing $500 \mathrm{ng} \mathrm{B}_{1}$ and $\mathrm{G}_{1}$, and $250 \mathrm{ng} \mathrm{B}_{2}$ and $\mathrm{G}_{2}$ for calculations.

Aflatoxins, $\mathrm{ng} / \mathrm{g}=\left(\mathrm{P} / \mathrm{P}^{\prime}\right) \times \mathrm{C} \times(2 / 10) \times 1000 \times \mathrm{D}$

Where $\mathrm{P}$ and $\mathrm{P}^{\prime}=$ peak areas (integrator counts) or heights for test solution and standard, respectively, per $25 \mathrm{~mL}$ injection; $\mathrm{C}=$ concentration of individual aflatoxins in standard solution $(0.5$ or $0.25 \mu \mathrm{g} / 10.05 \mathrm{~mL})$; and $\mathrm{D}=$ dilution factor if $2 \mathrm{~mL}$ test solution for injection is diluted.

\subsubsection{Detection of genetically modified imported corn and soybean}

Detection of genetically modified in eleven imported of yellow corn (code number from 1 to 11) and fourteen soybean (code number from 1 to 14) samples were determined at Plant Genetic Transformation Department, Agricultural Genetic Engineering Research Institute, Agricultural Research Center, Egypt. 


\subsubsection{DNA extraction:}

Genomic DNA was extracted from leaflets planted from seeds using the DNeasy plant mini kit (Qiagen, CA, USA) according to the manufacturer's instructions

\subsubsection{Estimation for the DNA concentration:}

\section{A. agarose gel}

Run $2 \mu \mathrm{l}$ of the parents DNA samples on $0.7 \%$ agarose gel in comparison to $5 \mu \mathrm{l}$ of a DNA size marker (100bp DNA ladder). To estimate DNA concentration, compare the degree of fluorescence of the DNA sample with the different bands in DNA size marker.

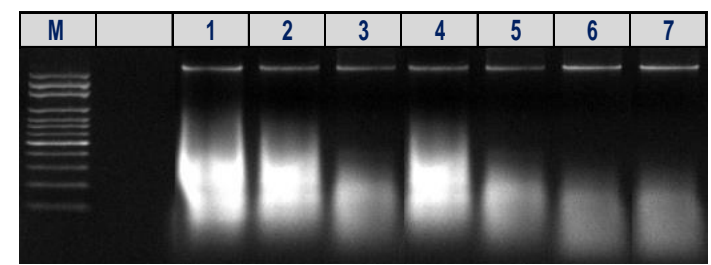

\section{Comparing fluorescence DNA sample with DNA marker's bands}

\section{B. Nano-drup}

The concentration of DNA was measured by (Nano drop)
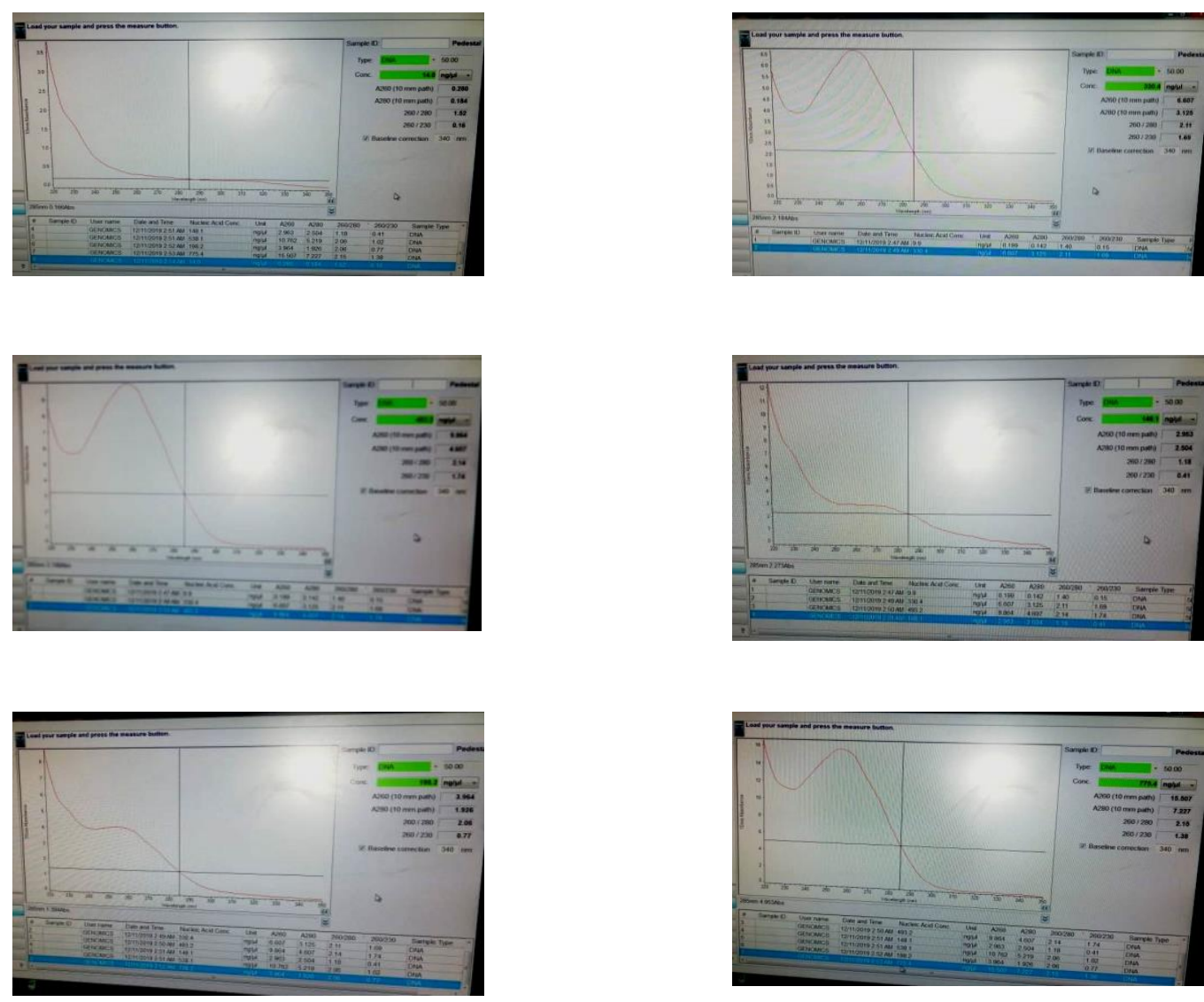
DNA concentration

\begin{tabular}{lllll}
\hline S.N & Con. & A260 & A280 & A260/A280 \\
\hline 1 & 14.0 & 0.280 & 0.184 & 1.52 \\
\hline 2 & 330.4 & 6.607 & 3.125 & 2.11 \\
\hline 3 & 493.2 & 9.864 & 4.607 & 2.14 \\
\hline 4 & 148.1 & 2.963 & 2.604 & 1.18 \\
\hline 5 & 538.1 & 10.762 & 5.219 & 2.06 \\
\hline 6 & 198.2 & 3.964 & 1.926 & 2.06 \\
\hline 7 & 775.4 & 15.507 & 7.227 & 2.15 \\
\hline
\end{tabular}

\subsubsection{Reproduction of DNA by using PCR device.}

PCR detection: The primers used to amplify the NOST (F\&R), $35 \mathrm{~S}$ promoter ( $f \& r)$ (1). DNA amplification was performed using $20 \mathrm{ng}$ of DNA template $250 \mathrm{mM}$ each dNTPs [dATP, dCTP, dGTP, dTTP], 25 pmol each primer, $2.5 \mathrm{mM} \mathrm{MgCl} 210 \mu \mathrm{l}$ of $5 \mathrm{x}$ PCR buffer and $2.5 \mathrm{U}$ Taq polymerase (promega) and added up to total volume of $50 \mu \mathrm{lddH} 2 \mathrm{O}$. The reactions were performed in an automatic thermal cycler (GeneAmp1 PCR System 9700, Perkin-Elmer) under the following conditions: initial denaturation at $94{ }^{\circ} \mathrm{C}$ for 3 min; 35 cycles of $94^{\circ} \mathrm{C}$ for $1 \mathrm{~min}, 46^{\circ} \mathrm{C}$ for $1 \mathrm{~min}, 72{ }^{\circ} \mathrm{C}$ for $1 \mathrm{~min}$; final extension at $72{ }^{\circ} \mathrm{C}$ for $7 \mathrm{~min}$. An aliquot of $10 \mu \mathrm{lPCR}$ product were analyzed on $1 \%$ agarose gel

\section{RESULTS AND DISCUSSION}

4.1. Proximate chemical composition of imported yellow corn and soybean compared with Egyptian varieties

Selected imported yellow corn and soybean samples compared with local Egyptian variety were analyzed for proximate chemical composition (Tables 1 and 2).

Table (1) show that imported yellow corn contained moisture from 8.63 to $9.58 \%$, protein ranged from 8.75 to $9.80 \%$, fat ranged from 3.48 to $4.0 \%$, fiber from 2.1 to $2.5 \%$ and ash from 1.0 to $1.5 \%$ while in Egyptian variety (SC128) moisture decreased to $6.6 \%$ and protein increased to $10.15 \%$.

These results are in agreement with the results of Gopalan et al., 2007 Sumbo and Victor, 2014 and Shah et al., 2016. Grain of higher moisture content is highly susceptible to deterioration (Gopaldas ,1988).

Generally, the low protein content of the grain limits its nutritive value as the only source of food for both humans and livestock. Maize grain is low in protein content $(9.1 \%)$, oil $(4.4 \%)$ and ash $(1.4 \%)$, but very high in starch content $(73.4 \%)$ when considered on dry matter basis (Herbert, 2017). The protein content of maize grain ranges from 8 to $11 \mathrm{~g} / 100 \mathrm{~g}$ grain of dry matter (Watson and Ramstad, 1987 and Martinez et al., 1996). 
It is reported that maize seeds have moisture (11.6-20.0\%), ash (1.10$2.95 \%)$, protein $(4.50-9.87 \%)$, fat $(2.17-4.43 \%)$, fiber $(2.10-26.70 \%)$ and carbohydrates contents (44.60-69.60\%) (Qamar et al., 2017).

Table (2) show that imported soybean contained moisture from 5.53to $6.75 \%$, protein ranged from 32.8 to $37.3 \%$, fat ranged from 16 to $20.8 \%$, fiber from 5.7 to $6.6 \%$ and ash from 5.1 to $5.3 \%$. Imported soybean sample No. 8 contained the lowest amount of protein while sample No. 1 and Egyptian variety (Giza 111) contained the highest amount of protein $37.8 \%$.

These results of proximate chemical composition of soybean are in agreement with many different publications (NRC, 1998 and Banaszkiewicz, 2011).

Soybean contains about $40 \%$ protein and is noteworthy as it is the most complete vegetable protein (Endres, 2001).

Generally soybean seeds content $5.6-11.5 \%$ of moisture, 32 to $43,6 \%$ of crude protein, 15.5 to $24.7 \%$ for fat and 4.5 to $6.4 \%$ for fiber (Ensminger et al., 1990, Poultry Feeding Standards, 2005 and Banaszkiewicz, 2011).

Sharma et al. (2014) published that soybean seeds contained moisture $(6.96 \mathrm{~g} / 100 \mathrm{~g})$, protein $(42.87 \mathrm{~g} / 100 \mathrm{~g})$, fat $(19.77 \mathrm{~g} / 100 \mathrm{~g})$, fiber $(5.06 \mathrm{~g} / 100 \mathrm{~g})$, ash $(5.59 \mathrm{~g} / 100 \mathrm{~g})$, carbohydrate (19.75 g/100 g dry weight).

The result of Etaiosa et al. (2017) showed that the soybean seed is rich in nutrient especially protein $37.69 \%$, crude fat $28.2 \%$ and fiber $6.31 \%$.

Recently, Jegadeesan and Kangfu (2020) indicated that soybeans possess average $20 \%$ oil and $40 \%$ protein content and are a major source of protein and fatty acids in human and animal nutrition. 
Table (1) proximate chemical composition of imported and local yellow corn samples*.

Code Moisture

No. of

Imported

Samples
(\%)
Chemical composition (\% DW)

\begin{tabular}{|c|c|c|c|c|}
\hline Prot & Fat & Fiber & Ash & $\begin{array}{c}\text { Nitrogen } \\
\text { Free Extract } \\
\text { NFE }\end{array}$ \\
\hline
\end{tabular}
NFE
1
$8.63 \pm$
$8.75 \pm 0.21$
$3.96 \pm$
$2.5 \pm 0.09 \quad 1.5 \pm 0.03$
$83.29 \pm 0.71$

0.21

0.11

4

$$
\begin{gathered}
9.07 \pm \\
0.20
\end{gathered}
$$

$8.75 \pm 0.23$

$3.48 \pm$

$2.3 \pm 0.08 \quad 1.2 \pm 0.05$

$84.27 \pm 0.50$

0.12

5

$9.52 \pm \quad 9.28 \pm 0.26$

$4.00 \pm$

$2.1 \pm 0.08 \quad 1.2 \pm 0.03$

$83.42 \pm 0.44$

0.23

0.12

$9 \quad 9.58 \pm$

$9.8 \pm 0.24$

$3.96 \pm$

0.10

$2.1 \pm 0.09 \quad 1.0 \pm 0.04$

$83.14 \pm 0.54$

Egypt

(SC128)

$6.6 \pm 0.18$

$10.15 \pm$

0.28

$3.72 \pm$

$2.4 \pm 0.10 \quad 1.4 \pm 0.02$

$82.33 \pm 0.67$ 0.11

*Mean of three replicates \pm SD

Table (2) proximate chemical composition of imported and local soybean samples

Code No. of Imported Samples
Moisture

(\%)
Chemical composition (\% DW)

$\begin{array}{llll}\text { Protein } & \text { Fat } & \text { Fiber } & \text { Nitrogen } \\ \text { Free Extract } & \text { NFE }\end{array}$

$1 \quad 5.53 \pm 0.22 \quad 37.3 \pm 0.51 \quad 20.8 \pm 0.32 \quad 5.7 \pm 0.20 \quad 5.1 \pm 0.24 \quad 31.1 \pm 0.61$

$3 \quad 6.47 \pm 0.21 \quad 33.6 \pm 0.50 \quad \begin{array}{cccc}18.88 \pm \\ 0.19\end{array} \quad 5.8 \pm 0.20 \quad 5.3 \pm 0.23 \quad 36.42 \pm 0.66$

$\begin{array}{lllllll}6 & 6.75 \pm 0.23 & 34.9 \pm 0.48 & \begin{array}{c}16.11 \pm \\ 0.15\end{array} & 6.4 \pm 0.23 & 5.3 \pm 0.25 & 37.4 \pm 0.68\end{array}$

$8 \quad 6.25 \pm 0.24 \quad 32.8 \pm 0.46 \quad 18.16 \pm \quad 6.6 \pm 0.22 \quad 5.1 \pm 0.27 \quad 37.34 \pm 0.71$

Egypt

(Giza

111)

$6.88 \pm 0.26 \quad 37.6 \pm 0.47 \quad 19.12 \pm$ 0.31

$6.4 \pm 0.23$

$5.3 \pm 0.26$

$31.58 \pm 0.68$

*Mean of three replicates \pm SD 


\subsection{Detection of aflatoxins in imported yellow corn and soybean}

Aflatoxins, during food storage or export, directly or indirectly result in the contamination of foods, which affects the liver, immune system and reproduction after infiltration into human beings and animals.

International Agency for Research on Cancer (IARC, 2012) classified aflatoxins $\mathrm{B} 1, \mathrm{~B} 2, \mathrm{G1}, \mathrm{G} 2, \mathrm{M} 1$ and $\mathrm{M} 2$ as group one carcinogenic substances, which are a global human health concern.

Selected yellow corn and soybean samples compared with local Egyptian variety (SC128 and Giza 111, respectively) were analyzed for aflatoxins detection at Central Laboratory of Residue Analysis of Pesticides and Heavy Metals in Food, Agriculture Research Center using liquid chromatography method (AOAC Official Method 990.33, 1990).

Tables (3-4) and Figure (1) showed that imported yellow corn and soybean samples as well as Egyptian corn variety (SC128) and soybean (Giza 111) were all free of aflatoxins.

It was established in about 1970 that fungal contamination could start in the field before harvest (Williams et al., 2004). Although the highest levels of aflatoxins are undoubtedly associated with post-harvest spoilage of food commodities stored under inappropriate conditions of water activity and temperature, the aflatoxigenic fungi have more complex ecologies (Moss, 2002). Factors that influence the incidence of fungal infection and subsequent toxin development include invertebrate vectors, grain damage, oxygen and carbon dioxide levels, inoculum load, substrate composition, fungal infection levels, prevalence of toxigenic strains and microbiological interactions.

Insect damage on crops allows fungi to access in them, increasing the chances of aflatoxins contamination, especially when loose-husked maize hybrids are used (Dowd, 2003 and Hell and Mutegi, 2011).

Controlling or reducing infection by regulating the factors that increase the risk of aflatoxins contamination in the field contributes extensively in managing aflatoxins. Management practices that reduce the incidence of aflatoxins contamination in the field include timely planting, maintaining optimal plant densities, proper plant nutrition, avoiding drought stress, controlling other plant pathogens, weeds and insect pests and proper harvesting (Bruns, 2003). Preharvest measures that are efficient in reducing aflatoxins levels are the same as those that will enhance yields. Crop rotation and management of crop residues also are important in controlling $A$. flavus infection in the field. Tillage practices, fertilizer application, weed control, late season rainfall, irrigation, wind and pest vectors affect the source and level of fungal inoculum, maintaining a disease cycle in crops like maize (Diener et al., 1987 and Hell and Mutegi, 2011). Lime application, use of farm yard manure and cereal crop residues as soil 
amendments have shown to be effective in reducing $A$. flavus contamination as well as aflatoxins levels by $50-90 \%$.

In order to minimize the levels of aflatoxins and mycotoxins in general, the National Institute of Agricultural Technology of Argentina (INTA), recommends to make early plantings, toplant resistant genotypes, to do good farming practices, to avoid stress conditions, to minimize insect damage, to harvest early in order to avoid delays, to avoid damaged kernels and to storage at less of $13 \%$ moisture in a clean, fresh and airy place with no insects (Iglesias et al., 2008). As mentioned before, it is important to avoid product moisture, high temperatures (between 25 and $32^{\circ} \mathrm{C}$ ) and high relative humidity in storage and seeds preservation. Weeds have to be removed and crop rotation should be done routinely. Prior to the preparation of the ground, dead organic matter has to be disabled or burned; product mechanical damage has to be avoided; crops have to be collected at full maturity; storage places should be dry and the entry of water has not to be allowed; storage health standards have to be fulfilled (pallets, proper humidity levels, adequate ventilation and lighting, etc.), and periodic inspection of the stored product should be done (Bolet et al., 2005).

\section{Table (3) Detection of Aflatoxins in imported and local yellow corn samples}

\begin{tabular}{ccccc}
\hline $\begin{array}{c}\text { Code No. of } \\
\text { Imported } \\
\text { Samples }\end{array}$ & \multicolumn{4}{c}{ Aflatoxins (mg/kg) } \\
\cline { 2 - 4 } $\mathbf{1}$ & B1 & B2 & G1 & G2 \\
4 & ND & ND & ND & ND \\
5 & ND & ND & ND & ND \\
9 & ND & ND & ND & ND \\
$\begin{array}{c}\text { Egypt } \\
\text { (SC128) }\end{array}$ & ND & ND & ND & ND \\
\hline
\end{tabular}

ND $=$ not detected 
A

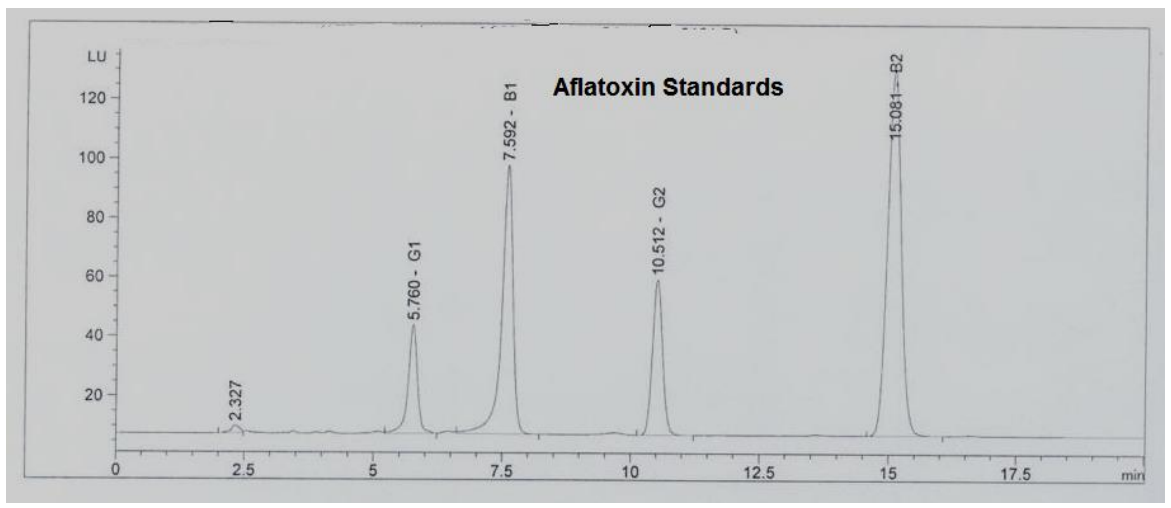

B

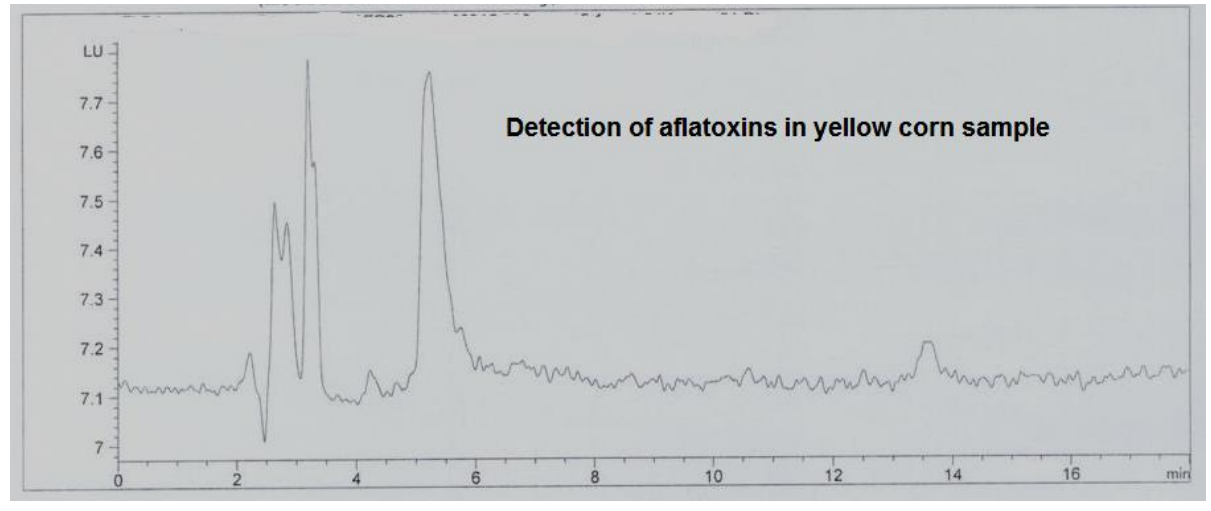

C

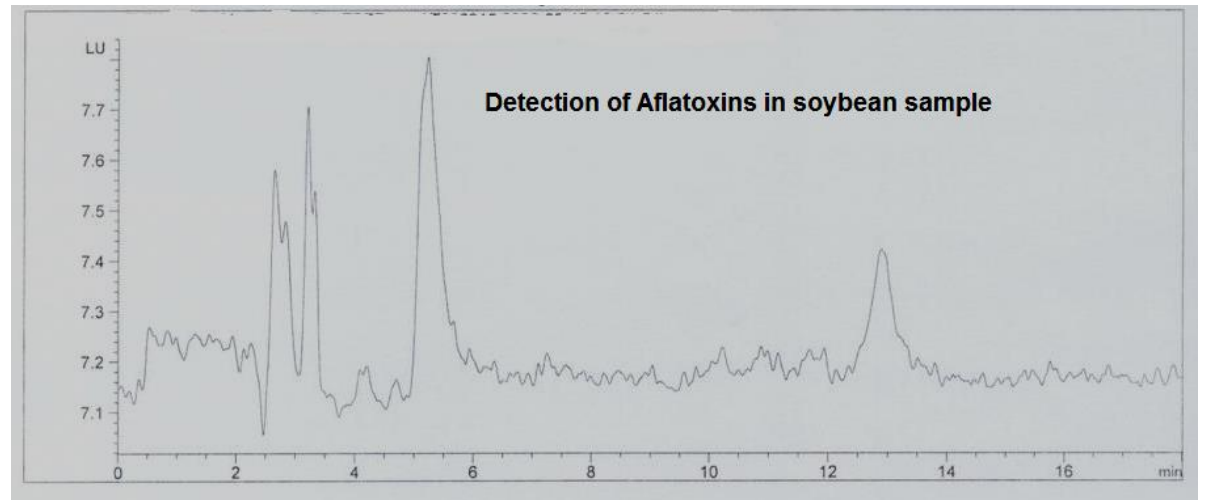

Figure 1. Detection of aflatoxins by Liquid Chromatography Method (AOAC, 1990)

A. Aflatoxins standards $\left(\left(G_{1}, B_{1}, G_{2}\right.\right.$ and $\left.B_{2}\right)$

B. Aflatoxins in yellow corn sample as an example

C. Aflatoxins in soybean sample as an example 


\subsection{Detection of genetically modified imported corn and soybean}

Genetically modified organisms (GMOs) have been mentioned to cause many risks to animals, human and the environment. According to Flachowsky et al. (2013) most of the produced GMOs products are used for animals feed.

This study is preformed to detect the presence of GMOs in the Egyptian imported corn and soybean.

Eleven imported yellow corn samples and fourteen imported soybean samples were tested for the detection GMOs at Plant Genetic Transformation Department, Agricultural Genetic Engineering Research Institute, Agricultural Research Center, Egypt.

The results of GM detected that $45 \%$ of total imported yellow corn samples (Code numbers 1, 5, 9, 10 and 11) were tested positive for NOS terminator and s335 promotor (Figure 2).

The results of GM detected that $50 \%$ of total imported soybean samples (Code numbers 1-4, 9, 10 and 14) were tested positive to NOS terminator and s335 promotor (Figure 3).

PCR is the most efficient and the most used technique worldwide, by using a specific primer for the identification of the inserted sequence in the gene it will show a consistent result (Marmirol et al., 2008). The used primers in PCR for the detection of GMOs, must have some specific characteristics. A new field of diagnostics will be represented by using this method which has been developed PCR was used to detect the presence of GM in some food samples such as corn, and soybean which are commercially imported and are available in Egyptian market (Korwin-Kossakowska et al., 2013).

The top 5 countries with the largest area of biotech crops planted (USA, Brazil, Argentina, Canada, and India) collectively occupied $91 \%$ of the global biotech crop area. Biotech soybeans reached the highest adoption worldwide, covering $50 \%$ of the global biotech crop area. The area of biotech crops with stacked traits continued to increase and occupied $42 \%$ of the global biotech area (EI Dahan, 2009 and ISAAA, 2017).

According to Olasoju et al. (2018), Egypt import large amount of cereal and legumes from outside and the most countries which Egypt import from is Ukraine, Bulgaria, brazil, Rumania and USA and these countries considered as the most countries which produce GMOs so the most cereals and legumes in the Egyptian market may be genetically modified (Abd-Elfattah et al., 2009 and Sadek, 2014).

This study is not a large survey (do not contain a huge amount of food products) about the extent of genetically modified organisms in the Egyptian market. There are a strongly recommendations for the need for a large scale survey that contain a large amount of food samples 


\section{Conclusion}

Chemical composition and detection of both aflatoxins and genetically modified organisms in imported yellow corn and soybean samples were investigated.

The results showed that yellow corn and soybeans imported from different countries contained high levels of protein and fat and free from aflatoxin as Egyptian varieties.

On the other side, the results of GMOs detected that $45 \%$ and $50 \%$ of total imported yellow corn and soybean samples were tested positive for NOS terminator and s335 promotor.

The Egyptian government should establish a policy to import high compositional quality crops that are free from fungal contamination and are not genetically modified, and to oblige importers to follow its rules. Imported shipments must be accompanied by documents stating that they are genetically modified or non-genetically modified.

A

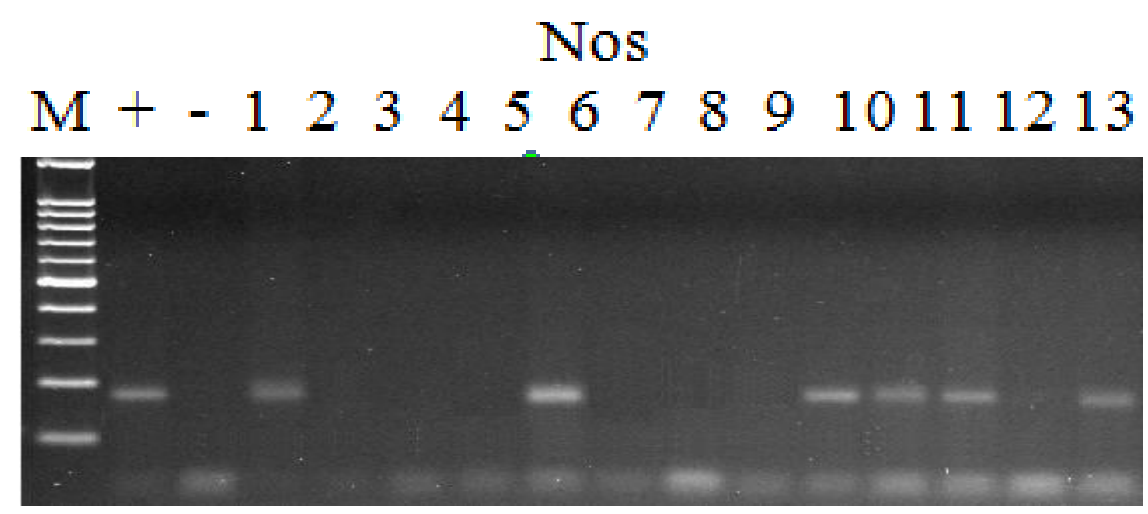

B

$35 \mathrm{~S}$

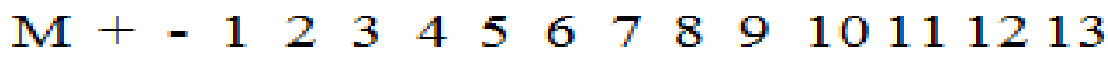

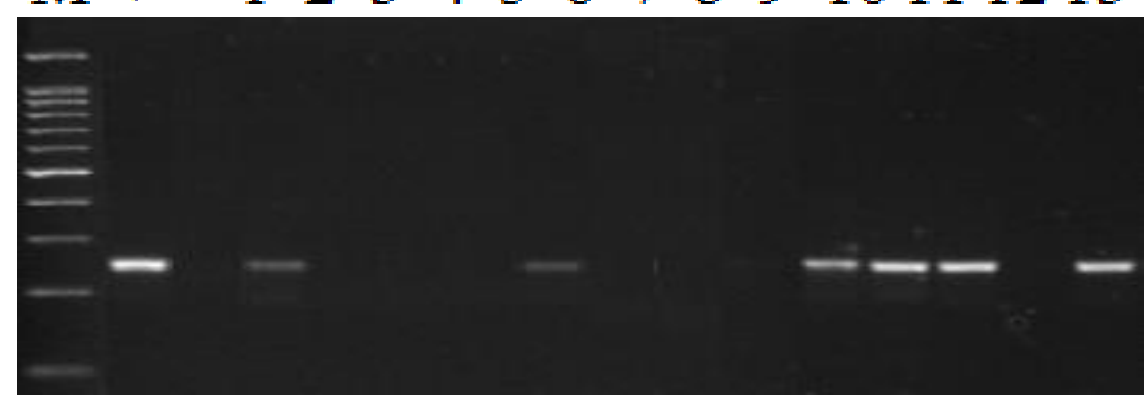

Figure 2. PCR confirmation analysis for detection GM in yellow corn samples. 
A: Using specific primers NOS F / R to amplify 200 bp of transgenic corn lines; lane M, 100bp DNA ladder; + control; - control; lanes 1 to 13 samples.

B: Using specific primers 35S F / R to amplify 210 bp of transgenic corn lines; lane M, 100bp DNA ladder; + control; - control; lanes 1 to 13sample, Positive samples were as follows samples 1, 5, 9, 10 and 11 while sample 13 is the repetition of sample 11

\section{A}

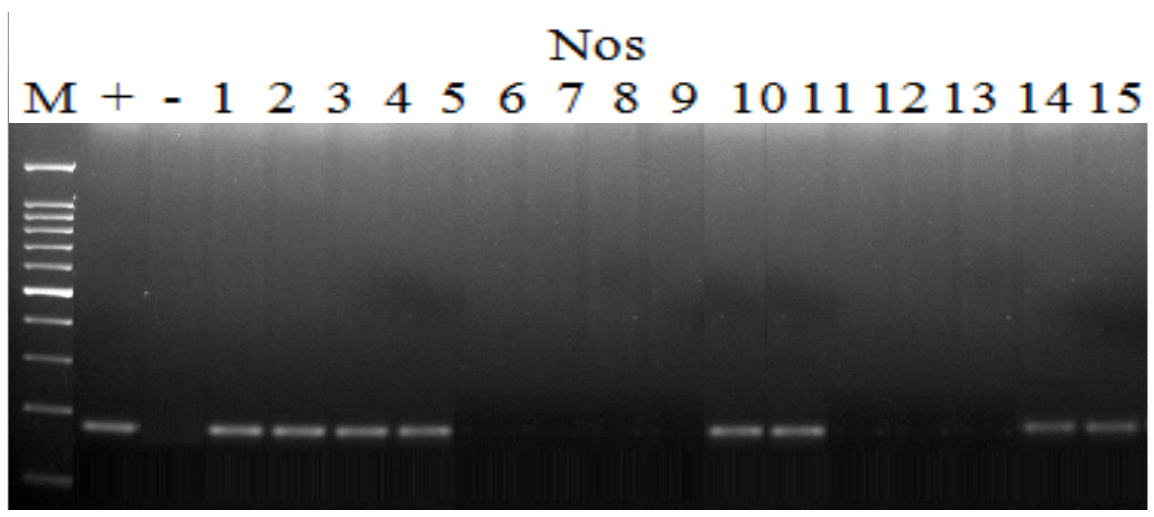

B

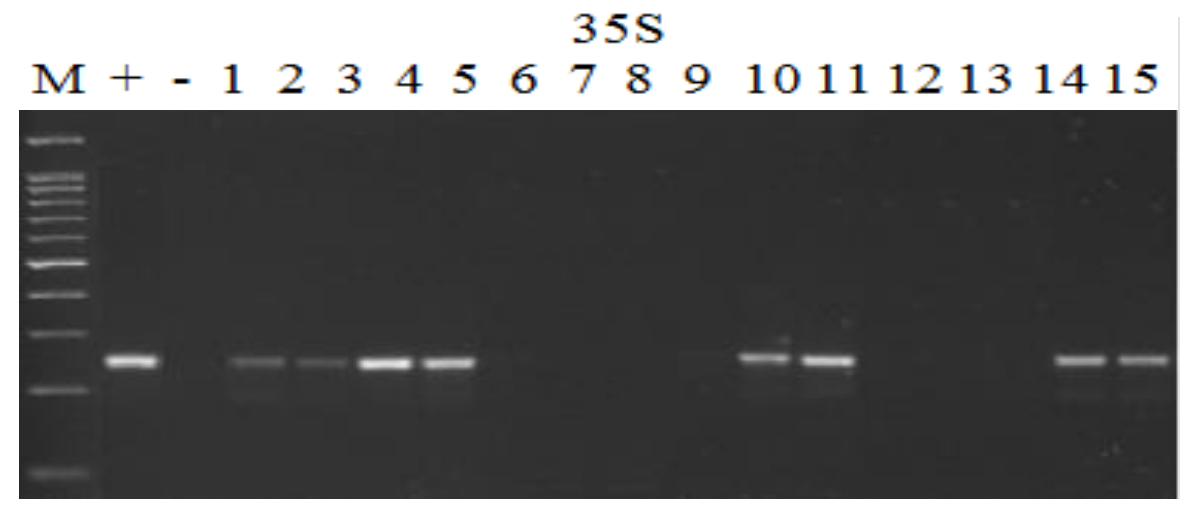

Figure 3. PCR confirmation analysis for detection GM in yellow corn samples.

A: Using specific primers NOS F / R to amplify 200 bp of transgenic soybean lines; lane M, 100bp DNA ladder; + control; - control; lanes 1 to15 samples.

B: Using specific primers 35S F / R to amplify 210 bp of transgenic soy lines; lane M, 100bp DNA ladder; + control; - control; lanes 1 to 15 sample, Positive samples were as follows lanes $1-4,9,10,14,15$ while sample 15 is the repetition of sample 14 . 


\section{REFERENCES}

Abd-Elfattah, M., Elsanhoty, M.R. and Osman,A.M. (2009). Occurrence of genetically modified food in Egyptian food market. J. Biol. Environ. Sci., 4, 759-777.

Abolude, D.S., Adelanwa, M.A., Adelanwa, E.B., Adamu, S.M. and Okafor, D.C. (2012). Morphological effects of sodium azide on soybean (Glycine max (L) Merr). Int. J. Scientific Res. 2, 115-123.

AOAC (1990). Aflatoxins in Corn and Peanut Butter using Liquid Chromatographic Method. Official Method 990.33

AOAC (2000). Association of Official Analytical Chemists. Official methods of Analysis (Vol. II 17th edition) of AOAC International. Washington, DC, USA. Official methods 960.52D, 1613-b and 923.03

Atmaca, E. , Guvenc, D. and Aksoy, A. (2015). Determination of Aflatoxin Levels in Maize Grain by High Performance Liquid Chromatography Using an Immunoaffinity Column Cleanup. PhD Thesis. Kafkas Univ., Turkey

Banaszkiewicz, T. (2011). Nutritional Value of Soybean Meal in Soybean and Nutrion. Edited by Hany A. El-Shemy Croatia InTech

Bolet, A. M. B. and Socarrás, S. M. M. (2005). Micotoxinas y cáncer. Revista Cubana de Investigaciones Biomédicas, 24, 54-59.

Bruns, H.A. (2003). Controlling aflatoxin and fumonisin in maize by crop management. Journal of Toxicology- Toxin Reviews, 22, 153-173.

Çakir O., Ucarli, C., Tarhan C. and Turgut-Kara, J. (2019). Nutritional and health benefits of legumes and their distinctive genomic properties. Food Sci. Technol, Campinas, 39, 1-12.

Diener, U. L., Cole, R. J., Sanders, T. H., Payne, G. A., Lee, L. S. and Klich, M. A. (1987). Epidemiology of aflatoxin formation by Aspergillus flavus. Annual Review of Phytopathology, 25, 230-240.

Dowd, P.F. (2003). Insect management to facilitate preharvest mycotoxin management. Journal of Toxicology- Toxins Reviews, 22, 327-350.

El-Hodairy, M.M.E. (2009). Detection of Corn Grains Contaminated by Aspergillus flavus Aflatoxins in Sebha and Tripoli grain Silos. M.Sc. Thesis. Sabha University, Libya

Endres, J.G. (2001). Protein quality and human nutrition. In: Endres JG, editor. Soy Protein Products: Characteristics, Nutritional Aspects, and Utilization. Revised and Expanded Edition.Champaign, Illinois, USA: AOCS; 2001.pp. 1019

Ensminger, M.E., Oldfield J.E. and Heinemann W.W. (1990). Feeds and Nutrition. The Ensminger Publishing Company, ISBN 09412180 82,Clovis, California 
Etiosa, O., Chika, N. and Benedicta, A. (2017). Mineral and Proximate Composition of Soyabean. Asian Journal of Physical and Chemical Sciences, 4, 1-6.

FAO/WHO. (2000). Safety aspects of genetically modified foods of plant origin. Report of a Joint FAO/WHO Expert Consultation on Foods Derived from Biotechnology, Geneva, Switzerland. Rome.

FAO/WHO (2001). Food and Agriculture Organization of the United Nations/World Health Organization. Evaluation of Allergenicity of Genetically Modified Foods. Report of a Joint FAO/WHO Expert Consultation on Allergenicity of Foods Derived from Biotechnology. Food and Agricultural Organization/World Health Organization. Rome, Italy.

FAS (2020). Foreign Agricultural Service. Grain and Feed Annual in Egypt. Report No: EG2020-0005

Feyera, M. (2020). Review on some cereal and legume based composite biscuits. Int. J. Agric. Sc. Food Technol., 6, 101-109.

Flachowsky, G., Gruen, M. and Meyer, U. (2013). Feed-efficient ruminant production: opportunities and challenges. Journal of Animal and Feed Sciences, 22, 177-187

Forte, V.; Di Pinto, A.; Martino, C.; Tantillo, G. M.; Grasso, G. and Schena, F. P. A. (2005). General multiplex-PCR Assay for the General Detection of Genetically Modified Soya and Maize. Food Control., 16, 535-539.

Gopalan, C., Rama Sastri, B. V. and Balasubramanian, S. (2007). Nutritive value of Indian foods. Hyderabad: National Institute of Nutrition (NIN), ICMR.

Gopaldas T (1988). Simple traditional methods for reducing the dietary bulk of cereal based diets in rural homes. In: Proceeding of the 20th annual meeting of the Nutrition Society of India. Hyderabad. Nutrition Society of India, 34, $73-84$.

Greiner, R. and Konietzny, U. (2008). Presence of Genetically Modified Maize and Soy in Food Products Sold Commercially in Brazil from 2000 to 2005. Food Control., 19, 499-505.

Hell, K. and Mutegi, C. (2011). Aflatoxin control and prevention strategies in key crops of Sub-Saharan Africa. African Journal of Microbiology Research, 5, 459-466.

Herbert K. D. (2017). Assessment of Maize (Zea mays) as Feed Resource for Poultry. http://dx.doi.org/10.5772/65363

IARC (2012). International Agency for Research on Cancer. Monographs on the evaluation of carcinogenic risks to humans: chemical agents and related occupations. A review of human carcinogens. Lyon, France: Pages, 224-248.

Iglesias, J., Presello, D. A., Fauguel, C. M. and Botta, G. L. (2008). Micotoxinas: Debemos preocuparnos? Presented at the 3 Jornada de 
Actualización Técnica de Maíz organized by Inta, Aianba, Maizar, Pergamino, Buenos Aires, Argentina.

ISAAA (2017). International Service for the Acquisition of Agri-biotech Applications Global Status of Commercialized Biotech/GM Crops in 2017: Biotech Crop Adoption Surges as Economic Benefits Accumulate in 22 Years No. 53

James, C. and Brief, S.S. (2011). Global Status of Commercialized biotech/GM Crops., ISAAA Brief, (44).

Jegadeesan, S. and Kangfu, Yu. (2020). Legume Crops - Prospects, Production and Uses. DOI: 10.5772/intechopen.92069 . Publisher: intechOpen

Kaur, J.; Radu, S.; Ghazali, F. M. and Kqueen, C. Y. (2010). Real-time PCRbased Detection and Quantification of Genetically Modified Maize in Processed Feeds Commercialised in Malaysia. Food Control., 21, 15361544.

Korwin-Kossakowska, A., Sartowska-Żygowska, K. and Linkiewicz, A. (2013). Evaluation of the effect of genetically modified $R R$ soya bean and $\mathrm{Bt}$ MON 810 maize in the diet of Japanese quail on chosen aspects of their productivity and retention of transgenic DNA in tissues. Archives Animal Breeding, 56, 1- 12.

El Dahan,M, E. (2009). Egypt Says No GM Food Exports or Imports. http://www.reuters.com/article/2009/08/12/us-egypt-foodUSTRE57B3VS20090812.

Mahler-Slasky, Y. and Kislev, M.E. (2010). Lathyrus consumption in late Bronze and Iron age sites in Israel: An Aegean affinity. Journal of Archaeological Science, 37, 2477-2485.

Mandaci, M., Cakir, O., Turgut-Kara, N., Meric, S. and Ari, S. (2014). Detection of genetically modified organisms in soy products sold in Turkish market. Food Sci. Technol, Campinas, 34, 717-722

Marmirol, N., a Maestri, E., Malcevsch, A. and De Bellis, G. (2008). Methods for detection of GMOs in food and feed. Analytical and Bioanalytical Chemistry, 392, 369-84

Martinez, B.F., Sevilla, P.E. and Bjarnason, M. (1996). Wet milling comparison of quality protein maize and normal maize. Journal of the Science of Food and Agriculture, 71, 156-162.

Medic, J., Atkinson, C. and Hurburgh, C. R. (2014). Current knowledge in soybean composition. JAOCS, J. Am. Oil Chem. Soc., 91, 363-384.

Metz, H. C. (1990). Egypt: A country study. Washington: GPO for the Library of Congress. 
Moss, M.O. (2002). Risk assessment for aflatoxins in foodstuffs. International Biodeterioration and Biodegradation, 50, 137-142.

Murshed, A.A.S, Bacha, N. and Alharazi, T. (2019). Detection of Total Aflatoxins in Groundnut and Soybean Samples in Yemen Using EnzymeLinked Immunosorbent Assay. Hindawi Journal of Food Quality,502, 7 -14.

National Research Council (NRC) (1998). Nutrient Requirements of Swine(Tenth revised Ed). National Academy Press, ISBN 0-309-05993-3, Washington DC. USA

Oladapo A.S., Adepeju, A.B., Akinyele, A.A and Adepeju, D.M. (2017). The Proximate, Functional and Anti-Nutritional Properties of Three Selected Varieties of Maize (Yellow, White and Pop Corn) Flour. International Journal of Scientific Engineering and Science, 1, 23-26.

Olasoju, S., Adekunle, O., Edun, T. and Owoseni, J. (2018). Problems and Prospects of Agricultural Biotechnology in Nigeria's Developing Economy. International Journal of Biological, Life and Agricultural Sciences,12, 24156612

Paarlberg, R. (2006). Are genetically modified (GM) crops a commercial risk for Africa? Int. J. Technology and Globalisation, 2, 81-92.

Poultry Feeding Standards (2005). Ed. The Kielanowski Institute of Animal Physiology and Nutrition, Polish Academy of Sciences, ISBN 83-917097-7-9, Jabłonna /Warszawa, Poland

Qamar, S., Aslam, M. Huyop, F. and Javed, M. (2017). Compartive study for the determination of nutritional composition in maize flour. Pak. J. Bot., 49(2): 519-523, 2017

Hafez,R, Mohammed, A., Abd El-Naby, A., Tolba, A., Khalifa, E., Hamed, H., Abdullah, M., Ahmed, M., Hekal, M. and Dalia Ali (2019). Changes in the Profiling of Fatty Acids of Glycine max L. (Soybean) Callus after Mutagen Treatments. Egypt. J.Bot., 59, 679-694

Rodrigues, S.I., Ribeiro, A. M. and McManus, C.M. (2014). Quality Assessment of Corn Batches Received at a Feed Mill in the Brazilian Cerrado. Brazilian Journal of

Sadek,G H. (2014), Senior Legal Research Analyst. Restrictions on Genetically Modified Organisms, Egypt.Poultry Science, 16, 233-240

Shah, T., Prasad, K. and Kumar, P. (2016). Maize-A potential source of human nutrition and health: A review. Cogent Food \& Agriculture 2, 1-9

Shamsuddeen, U., Ahmad, M. A. and Abdulkadir, R. S. (2017). Evaluation of Aflatoxin Contamination in Zea mays (Maize) Sold in Katsina Central Market, Nigeria. UMYU Journal of Microbiology Research, 2, 102-106. 
Sharma, D., Gupta, R. and Joshi, I. (2014). Nutrient Analysis of Raw and Processed Soybean and Development of Value Added Soybean Noodles. Inventi Rapid: Life Style Vol. 2014, Issue 1, 1-10.

Shetty, M., Chandan, K. and Aparna, G.S. (2018). Genetically modified crops: An overview. Journal of Pharmacognosy and Phytochemistry, 7, 2405-2410

Sparrow, P.C. (2018). GM risk assessment. Molecular biotechnology, 44, $267-$ 275

Sumbo, A. and Victor, I. (2014). Comparison of chemical composition, functional properties and amino acids composition of quality protein maize and common maize. African Journal of Food Science and Technology, 5, 8189

Ubwa, T.S, Asemave, K., and Igbum, O.G. (2012). Preliminary screening of aflatoxin level in maize (Zea mays L.) in some selected markets in Benue State, Nigeria. African Journal of Pure and Applied Chemistry, 6, 159-163.

Watson, S.A., Ramstad, P.R. (1987). Corn Chemistry and Technology. St Paul: American Association of Cereal Chemists. 19, 605 - 610.

Williams, J. H., Phillips, T. D., Jolly, P. E., Stiles, J. K., Jolly, C. M. and Aggarwal, D. (2004). Human aflatoxicosis in developing countries: a review of toxicology, exposure, potential health consequences, and interventions. American Journal of Clinical Nutrition, 80, 1106 -1122.

Zohry, A., Ohry, S. and Noreldin, T. (2016). Solutions for maize productionconsumption gap in Egypt. 
الملخص

التركيب الكيماوى والكثف عن الأفلاتوكسين والتعديل الوراثى في الذرة الصفراء وفول الصويا المستوردة

أيمن محمد أبو اليزيد أحمد السبد عبدالله

\section{أمبمه السبد شلتوت}

** مشام محمد الششتاوى

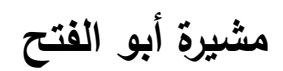

سعيد محمد خليل

قسم علوم الأغذية - كليه الزراعة سابا باشا - جامعة الإسكندرية

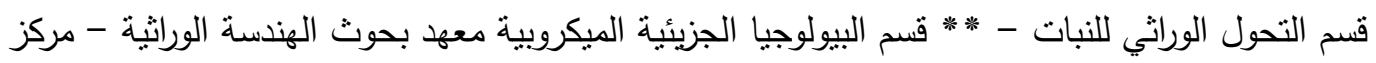

"البحوث الزراعية

خلال الأعوام القليله الماضية وحتى الأن ينت تعويض الفجوة بين إنتاج واستهلاك الحبوب مثل الذرة والبقوليات مثل فول الصويا في مصر عن طريق الاستيراد من دول مختلفة.

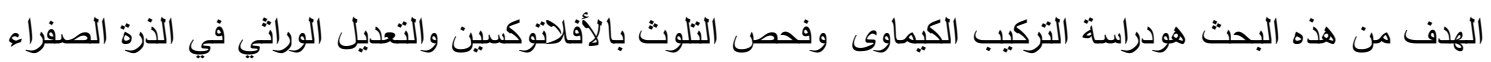
وفول الصويا المستوردة. أوضحت نتائج التركيب الكيماوى التقريبي أن عينات الذرة الصفراء المستوردة تحتوى علي البروتين الذي يتراوح

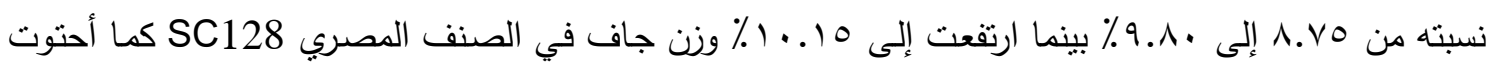

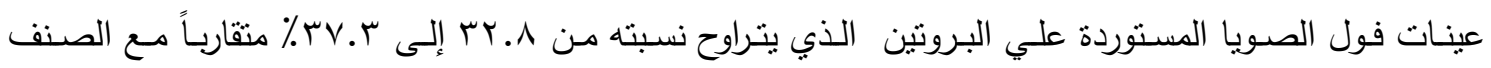
المصرى جيزة 111 .

أظهرت نتائج التحليل الكروماتوجرافي أن جميع عينات الذرة والصويا المستوردة والمحليه كانت خالية تماما من التلوث بالأفلاتوكسينات.

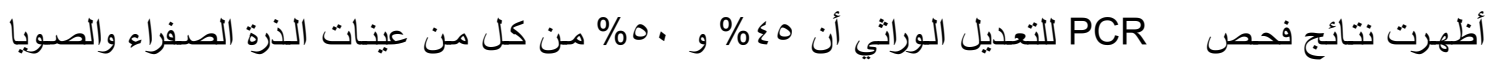
المستوردة كانت معدله وراثياً. تستورد مصر كميات مرتفعة من الحبوب والبقوليات من أوكرانيا وبلغاريا والبرازيل ورومانيا والولايات المتحدة والتي كعي

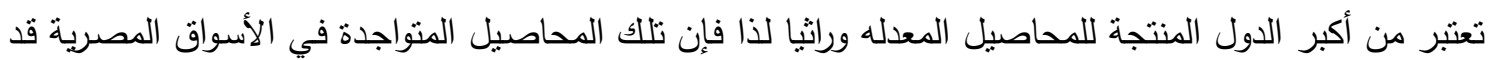
تكون معدله وراثياً.

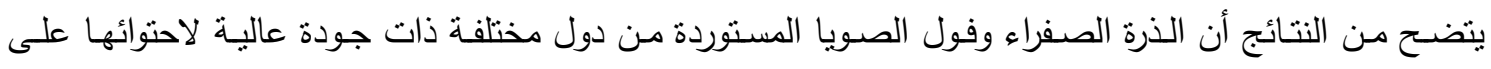

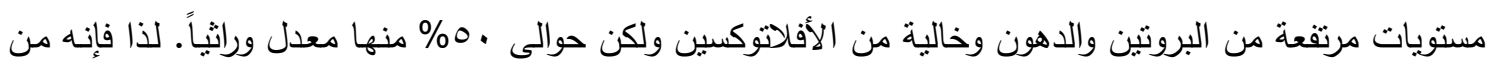
الضروري الكثف عن التعديل الوراتي في مثل تلك المحاصيل والتي تدخل في العديد من الصناعات الغذائيسة حرصا علي سلامة وجودة الغذاء وأيضا سلامة المستهلك.

يجب علي الحكومه المصرية وضع سياسة لإسنيراد محاصيل ذو جودة عاليه وخاليه من التلوث بالفطريات وغير معدله وراثيا وإلزام المستوردين بإنباع قواعدها. ويجب أن تكون الثحنات المستوردة مصحوبة بمستندات تفيد بانها معدلة وراثيا أو غير معدله وراثياً. 
